\title{
Változások a pulmonalis hypertonia 2015. évi irányelvében
}

\author{
Forster Tamás dr. \\ Szegedi Tudományegyetem, Általános Orvostudományi Kar, Szent-Györgyi Albert Klinikai Központ, \\ II. Belgyógyászati Klinika és Kardiológiai Központ, Szeged
}

\begin{abstract}
Az Európai Kardiológiai Társaság és az Európai Légzéstudományi Társaság új, 2015. évi ajánlása finomította a pulmonalis hypertonia diagnosztikus kritériumait. Új diagnosztikus algoritmust javasoltak a kivizsgálás menetére. Az új gyógyszerek bevonásával megújították a terápiás algoritmust is. A hagyományos, szekvenciális kombináció mellett megfogalmazták az azonnali (iniciális) kombináció lehetőségét is. Ráirányítják a figyelmet a centrumban történő kezelés kiemelkedő szerepére. Orv. Hetil., 2016, 157(38), 1522-1525.
\end{abstract}

Kulcsszavak: pulmonalis hypertonia, irányelv

\section{Changes in the 2015 guideline of pulmonary hypertension}

The new 2015 ESC/ERS Guideline refined the diagnostic criteria of pulmonary hypertension. A new diagnostic algorithm is suggested. The therapeutic algorithm is renewed on the basis of newly registered drugs. Besides the usual sequential combination, the immediate (initial) combination is proposed as an alternative way. Pulmonary hypertension should be treated in expert referral centers.

Keywords: pulmonary hypertension, guideline

Forster, T. [Changes in the 2015 guideline of pulmonary hypertension]. Orv. Hetil., 2016, 157(38), 1522-1525.

(Beérkezett: 2016. július 22.; elfogadva: 2016. július 26.)

\section{Rövidítések}

ERS = Európai Légzéstudományi Társaság; ESC = Európai Kardiológiai Társaság

Az Európai Kardiológiai Társaság (ESC) 2009-es szakmai irányelvét követően új információk láttak napvilágot a pulmonalis hypertonia diagnózisáról és kezeléséról. 2013-ban az 5. Pulmonalis Hypertonia Világszimpózium kapcsán Nizzában már összegezték az addig összegyúlt adatokat. Időközben azonban számos változás történt, új gyógyszerek kerültek forgalomba, így indokolt volt 2015-ben a legújabb eredmények figyelembevételével azok összefoglalása egy új irányelvben, amelyet a Magyar Kardiológusok Társasága is befogadott. Az ajánlás az Európai Légzéstudományi Társasággal (ERS) egyetértésben készült el [1, 2].

\section{A pulmonalis hypertonia definíciója}

A diagnózis alapja továbbra is a $25 \mathrm{Hgmm}-\mathrm{t}$ meghaladó pulmonalis artériás középnyomás, amelyet jobbszívfélkatéterezéssel határozunk meg. A klinikai jelentősége a 21-24 Hgmm közötti pulmonalis nyomásnak egyelőre nem tisztázott, de azon eseteket, ahol progresszió várható (például kötőszöveti betegség, genetikai eredet), szorosabban kell követni. A terhelés indukálta pulmonalis nyomásemelkedés szerepe mellett továbbra sem szólnak meggyőzó érvek, ez továbbra sem szerepel a definícióban.

A praecapillaris pulmonalis hypertoniában a pulmonalis capillaris wedge (ék) nyomás $15 \mathrm{Hgmm}$ alatt van. Ezen érték felett postcapillaris pulmonalis hypertoniáról beszélünk. A definíciót tovább finomították a diasztolés nyomásgradiens és a pulmonalis vascularis rezisztencia 
alapján. Ha a diasztolés pulmonalis nyomásgradiens 7 Hgmm alatt van, akkor izolált postcapillaris pulmonalis bypertoniáról van szó, ha nagyobb, mint 7 Hgmm és a pulmonalis vascularis rezisztencia meghaladja a 3 Wood egységet, akkor kombinált postcapillaris pulmonalis bypertoniáról beszélünk.

\section{Klasszifikáció}

A pulmonalis hypertonia klasszifikációja lényegesen nem változott az előző ajánláshoz képest (1. táblázat). A besorolás alapja a hasonló klinikai megjelenés, patológiai

\section{1. táblázat A pulmonalis hypertonia felosztása}

1. Pulmonalis artériás hypertonia $(P A H)$

1.1. Idiopathiás

1.2. Örökletes

1.3. Gyógyszer indukálta

1.4. Más betegséghez csatlakozó (APAH)

1.4.1. Kötőszöveti betegség

1.4.2. HIV-fertőzés

1.4.3. Portalis hypertensio

1.4.4. Congenitalis vitiumok

1.4.5. Schistosomiasis

I'. Pulmonalis venoocclusiv betegség és/vagy pulmonalis kapilláris baemangiomatosis

1’. Újszülöttkori perzisztáló pulmonalis hypertonia

2. Pulmonalis hypertonia balszinfél-betegség következtében

2.1. Szisztolés diszfunkció

2.2. Diasztolés diszfunkció

2.3. Billentyúbetegség

2.4. Congenitalis balszívfél-obstrukció vagy cardiomyopathia

2.5. Congenitalis pulmonalis vénás stenosis

3. Tüdöbetegség vagy hypoxaemia miatti pulmonalis hypertonia

3.1. COPD

3.2. Interstitialis tüdőbetegség

3.3. Kevert obstruktív-restriktív tüdőbetegség

3.4. Alvási hypoxia

3.5. Alveolaris hypoventilatio

3.6. Hegyi betegség

3.7. Fejlődési rendellenesség

4. Krónikus thromboemboliás pulmonalis hypertonia (CTEPH) és más pulmonalis artériás obstrukciók

5. Pulmonalis hypertonia ismeretlen vagy multifaktoriális okból

5.1. Krónikus haemolyticus anaemia, myeloproliferativ betegség

5.2. Sarcoidosis, pulmonalis histiocytosis

5.3. Metabolikus kórokok, glikogéntárolási betegség

5.4. Szegmentális pulmonalis hypertonia, fibrotizáló medias eltérés vagy hemodinamikai jellemző. Az 1., a 3., a 4. és az 5. osztály egy része a praecapillaris pulmonalis hypertonia, míg a 2 . osztály és az 5 . osztály másik része a postcapillaris pulmonalis hypertonia csoportjába tartozik. Az 1. Osztály neve elkülönül a többi négy osztályétól - pulmonalis artériás hypertonia -, jelezvén, hogy ennek az osztálynak a kezelése más elvek alapján, más gyógyszerekkel történhet. Az l. osztályba soroljuk az ismeretlen eredetű, idiopathiás formákat, az örökletes eseteket, de idesorolódik a gyógyszerek által kiváltott betegség is. Egy jelentős csoportja az 1. osztálynak a más betegségekhez kapcsolódó okok sora, mint például a kötőszöveti betegséghez, a veleszületett szívbetegségekhez vagy a portalis hypertoniához kapcsolódó pulmonalis hypertonia formák. Fertőzések (például HIV vagy schistosomiasis) is lehetnek a pulmonalis hypertonia okai. Az 1. osztály két „alcsoportja” a pulmonalis venoocclusiv betegség és/vagy pulmonalis kapilláris haemangiomatosis, amelyek ritka formák, illetve most került be az újszülöttkori perzisztáló pulmonalis hypertonia.

\section{Diagnózis}

A klinikai tünetek általában nem specifikusak (nehézlégzés, gyengeség, köhögés, esetleg syncope). Súlyos állapotban a jobbszívfél-elégtelenség tünetei már jól felismerhetők.

A klinikai tünetek és a fizikális vizsgálat alapján felmerülő gyanú fennállása esetén a diagnózist igazolni szükséges, illetve a betegség különböző formáit differenciálni kell. Ehhez a diagnosztikus armamentárium minden elemét, a klasszikus módszerek (EKG, mellkasröntgen) mellett a legkorszerúbb diagnosztikai technikákat (CT, $\mathrm{MR}$ ) is alkalmazni kell.

Az echokardiográfia kulcsszerepet játszik a pulmonalis hypertonia diagnózisában. A pulmonalis nyomás becslésére a tricuspidalis insufficientia Dopplerrel mért sebességét használhatjuk (2. táblázat). Emellett más echokardiográfiás jelek is utalhatnak a pulmonalis nyomásemelkedésre (3. táblázat).

2. táblázat A pulmonalis hypertonia valószínúségének osztályozása echokardiográfiás vizsgálat alapján

\begin{tabular}{lll}
\hline $\begin{array}{l}\text { Csúcs tricuspidalis } \\
\text { regurgitatiós sebesség } \\
(\mathrm{m} / \mathrm{s})\end{array}$ & $\begin{array}{l}\text { Egyéb PH-ra utaló } \\
\text { ECHO-jel }\end{array}$ & $\begin{array}{l}\text { PH valószínúsége } \\
\text { ECHO-vizsgálat } \\
\text { alkalmazásával }\end{array}$ \\
\hline $\begin{array}{l}\leq 2,8 \text { vagy nem } \\
\text { mérhető }\end{array}$ & Nem & Alacsony \\
\hline $\begin{array}{l}\leq 2,8 \text { vagy nem } \\
\text { mérhető }\end{array}$ & Igen & Közepes \\
$2,9-3,4$ & Nem & Magas \\
\hline $2,9-3,4$ & Igen & \\
$>3,4$ & Nem szükséges &
\end{tabular}


3. táblázat $\mid$ Pulmonalis hypertoniára utaló egyéb ECHO-jelek a pulmonalis hypertonia valószínúségének meghatározására

\begin{tabular}{|c|c|c|}
\hline A) Kamrák & B) Pulmonalis artéria & $\begin{array}{l}\text { C) Inferior vena cava } \\
\text { és jobb pitvar }\end{array}$ \\
\hline $\begin{array}{l}\text { Jobb kamra/bal } \\
\text { kamra bazális } \\
\text { átméró arány } \\
>1,0\end{array}$ & $\begin{array}{l}\text { Jobb kamrai kiáramlási } \\
\text { Doppler akcelerációs } \\
\text { idő < } 105 \mathrm{~m} / \mathrm{sec} \text { és/ } \\
\text { vagy mid-szisztolés } \\
\text { behúzódással }\end{array}$ & $\begin{array}{l}\text { Inferior cava átmérő } \\
>21 \mathrm{~mm} \text { csökkent } \\
\text { belégzési collapsussal } \\
\text { (<50\% mélyebb } \\
\text { belégzéskor vagy <20\% } \\
\text { enyhe belégzéskor) }\end{array}$ \\
\hline $\begin{array}{l}\text { Interventricularis } \\
\text { septum } \\
\text { benyomódása } \\
\text { (bal kamra } \\
\text { excentricitási } \\
\text { index >1,0, } \\
\text { szisztoléban } \\
\text { és/vagy } \\
\text { diasztoléban) }\end{array}$ & $\begin{array}{l}\text { Korai diasztolés } \\
\text { pulmonalis } \\
\text { regurgitatiós sebesség } \\
>2,2 \mathrm{~m} / \mathrm{sec}\end{array}$ & $\begin{array}{l}\text { Jobb pitvar felülete } \\
\text { (végszisztolés) }>18 \mathrm{~cm}^{2}\end{array}$ \\
\hline
\end{tabular}

Ha az echokardiográfiás vizsgálat alapján a pulmonalis hypertonia valószínűsége magas, akkor minden esetben további diagnosztikus vizsgálatok javasoltak (beleértve a jobbszívfél-katéterezést is). Alacsony valószínűség esetén további vizsgálatok nem indokoltak. Közepes valószínüség fennállásakor echokardiográfiás utánkövetés javasolt, jobbszívfél-katéterezés csak akkor mérlegelendő, ha egyéb rizikófaktorok is jelen vannak.

Egy új diagnosztikus algoritmust is javasoltak. A kivizsgálást az echokardiográfiás lelet alapján kell megindítani. A 2., illetve 3. osztály betegségeinek kizárását követően a beteget mindenképpen indokolt szakértői centrumba irányítani a további vizsgálatok vezetésére. $\mathrm{Az}$ algoritmus alapján fokozatosan zárjuk ki az egyéb okokat, míg végül megmarad a pulmonalis artériás hypertonia (PAH - 1. osztály), amelyen belül specifikus tesztek segítenek az egyes formák azonosításában.

\section{Pulmonalis artériás hypertonia}

\section{Súlyosság megitélése}

A pulmonalis artériás hypertonia súlyosságának megítélése a szokásos elvek szerint történik. A részletes kivizsgálást szakértői centrumban indokolt elvégezni. Felmérjük a beteg funkcionális állapotát a WHO-kritériumok szerint. Értékeljük a fizikai állapotot a 6 perces járástávolság (6MWD) lemérésével, illetve a cardiopulmonalis terheléses vizsgálattal. Az echokardiográfia nemcsak a diagnózis felállítása során hasznos, hanem a folyamatos követésben is fontos szerepe van. BNP (vagy NT-proBNP) mind a diagnózis során, mind a későbbi követés alkalmával hasznos állapotjelző. Jobbszívfél-katéterezés a diagnózis felállításakor elengedhetetlen, később a klinikai állapot rosszabbodása, a terápia elégtelensége esetén is indokolt megismételni. A szerteágazó, többparaméteres megítélés azért szükséges, mert nincs „egyetlen” olyan érték, amely önmagában jelezné az állapotot és a prognózist. Az első észlelés alkalmával minden vizsgálatot el kell végezni.

\section{Rizikóbecslés}

Újdonság, hogy az alacsony, közepes és magas rizikójú kvalitatív kategóriák mellett a várható halálozást is hozzárendelték. Így a becsült 1 éves mortalitás alapján a három rizikókategória a következő lesz: alacsony rizikó $(<5 \%)$, közepes rizikó $(5-10 \%)$ és magas rizikó ( $>10 \%)$. A rossz klinikai kimenetelt előre jelző paramétereket a 4. táblázat mutatja be.

Olyan természetesen nincs, hogy egy beteg minden paramétere ugyanabba a kategóriába esik, ezért meghatározzuk az egyes szempontok szerint a rizikó mértékét, majd összesítve értékeljük a várható „összesített” rizikó nagyságát.

A betegek rendszeres ellenörzése 3-6 havonta indokolt, amely során a rizikófelmérést minden esetben el kell végezni. Magyarországon a gyógyszerfelírási szabályok miatt a 3 havonta történő ellenőrzés tűnik racionálisnak.

\section{Terápia}

A 2-5. osztályok esetében az alapbetegség kezelése indokolt. A pulmonalis artériás hypertonia felismerését követően a betegnek életviteli tanácsokat kell adnunk. Terhesség kiviselésétől tartózkodni kell. Kontrollált fizikai aktivitás megfontolható, de erőteljes fizikai terhelés egyértelműen kerülendő. Oxigén- jobbszívfél-elégtelenség tünetei esetén diuretikum feltétlenül javasolt. Orális antikoaguláns adása szintén megfontolható.

Pozitív vazoreaktivitási teszt után nagy dózisú kalciumcsatorna-blokkoló adása javasolt. A vazoreaktivitási tesztet időről időre meg kell ismételni, hogy az állapot

4. táblázat |A rossz prognózis előrejelzői
- Jobbszívfél-elégtelenség tünetei
- Gyors progresszió
- Ismételt syncopék
- WHO FC IV.
- $6 \mathrm{MWD}>165 \mathrm{~m}$
- Csúcs- $-\mathrm{VO}_{2}<11 \mathrm{ml} / \mathrm{min} / \mathrm{kg}$
- $\quad$ BNP $>300 \mathrm{ng} / \mathrm{l}$ vagy NT-proBNP $>1400 \mathrm{ng} / \mathrm{l}$
- JP-area $>26 \mathrm{~cm}_{2}$
- Pericardialis folyadék látható
- Jobb pitvari nyomás >14 Hgmm
- Perctérfogatindex $<2,01 / \mathrm{min} / \mathrm{m}^{2}$
- Vénás $\mathrm{O}_{2}$-szaturáció $<60 \%$ 
még mindig fennáll-e. A teszt negatívvá válása esetén át kell térni az egyéb vazodilatátor kezelésre.

A patofiziológiai mechanizmus alapján továbbra is a három fó gyógyszercsoport használatos: az endothelinreceptor-antagonisták, foszfodiészteráz-5-gátlók és a prosztaciklinszármazékok. Három új gyógyszer is befogadásra került. Az endothelinreceptor-antagonisták egy új szere a macitentan. A szolúbilis guanil-cikláz enzimstimulátor riociguat hatása alapján a foszfodiészteráz5-gátlókkal kerül egy csoportba. A selexipag bár nem prosztaciklinszármazék, de hatásában idesorolható, ez egy új prosztaglandinreceptor-agonista szer. A prosztaciklinszármazékok jelenleg elsősorban parenteralisan adandók, míg a selexipag orális készítmény. Ezen új szerekkel végzett multicentrikus vizsgálatok igen kedvező eredményt adtak.

Az ajánlás alapján a kezelés a WHO FC II-IV. stádiumokban indokolt. A kezelés alapelve, hogy a beteget lehetőleg WHO FC I. stádiumba hozzuk és tartósan itt tartsuk. Ehhez alkalmazhatunk monoterápiát, nem megfelelő klinikai válasz esetén kettős vagy hármas kombinációt is (ez az úgynevezett szekvenciális kombináció). WHO FC II. stádiumban elsősorban a per os adható készítmények javasoltak, WHO FC III. stádiumban ezen szerek mellett használhatjuk a különböző prosztaciklinszármazékokat (intravénás, subcutan, inhalációs). WHO FC IV. stádiumban egyedül az intravénás epoprostenolnak van erős indikációja.

Az új ajánlás teret enged az azonnali kombinációs kezelés indításának is bizonyos esetekben (ez az úgynevezett initial vagy upfront kombináció). Kettős vagy akár hármas kombináció is lehetséges. Magas rizikójú betegben (WHO FC IV.) azonnali kombináció javasolt egyik szerként iv. prosztaciklin adásával.

Amennyiben a gyógyszeres kezelés nem jár kielégító eredménnyel és a klinikai állapot progrediál, akkor tüdőtranszplantációval segíthetünk csak. Ha WHO FC III. stádiumban a beteg állapota a kezelés ellenére sem javul, akkor már érdemes a transzplantációs központtal felvenni a kapcsolatot és a beteget is tájékoztatni egy lehetséges mütéti beavatkozás lehetőségéről.

\section{Pulmonalis hypertonia központ kritériumai}

Az ajánlás kifejezetten javasolja, hogy a pulmonalis hypertoniás betegek kivizsgálása és kezelése szakosodott centrumban történjen. A centrumnak legyen közvetlen elérhetősége a kötőszöveti betegségekkel, a felnőtt congenitalis betegeket kezelő specialistákkal, illetve a tüdőtranszplantációt végző kollégákkal.

A centrum kritériumai közé tartozik, hogy körülbelül 50 beteget kövessen pulmonalis hypertoniával vagy krónikus thromboemboliás formával (CTEPH). Évente mintegy 20 vazoreaktivitási tesztet kellene végezni a központban. Elvárható, hogy a centrum részt vegyen pulmonalis hypertoniával foglalkozó multicentrikus kutatásokban is.

Anyagi támogatás: A közlemény megírása anyagi támogatásban nem részesült.

A szerző a cikk végleges változatát elolvasta és jóváhagyta.

Érdekeltségek: Előadás tartása az Actelion Pharmaceuticals Hungarica Kft.-nél.

\section{Irodalom}

[1] Galié, N., Humbert, M., Vachiery, J. L., et al.: 2015 ESC/ERS Guidelines for the diagnosis and treatment of pulmonary hypertension. The Joint Task Force for the Diagnosis and Treatment of Pulmonary Hypertension of the European Society of Cardiology (ESC) and the European Respiratory Society (ERS). Endorsed by: Association for European Paediatric and Congenital Cardiology (AEPC), International Society for Heart and Lung Transplantation (ISHLT). Eur. Heart J., 2016, 37(1), 67-119.

[2] Pulmonary hypertension. ESC Pocket Guidelines 2016. https:// www.escardio.org/Guidelines-\&-Education/Clinical-PracticeGuidelines/Guidelines-derivative-products/ESC-Mobile-Pocket-Guidelines

(Forster Tamás dr., Szeged, Semmelweis u. 8., 6725 e-mail: forster.tamas@med.u-szeged.hu) 